\title{
KAJIAN PENGEMBANGAN KETERSEDIAAN RUANG TERBUKA HIJAU TAMAN KOTA
}

\author{
M. ICHWAN SYABANA ${ }^{1)}$, ANNISA BUDHIYANI TRI BHUWANESWARI'). \\ ${ }^{1,2,3}$ Program Studi Perencanaan Wilayah Dan Kota, Fakultas Teknik Sipil Dan Perencanaan, Universitas \\ PGRI Adi Buana Surabaya \\ Email; ichwansyabana11@gmail.com
}

\begin{abstract}
Abstrak
Perkotaan Pamekasan memiliki luas 7.290 ha dengan jumlah penduduk pada tahun 2017 sebanyak 174.045 jiwa. Seiring dengan pertumbuhan penduduk yang semakin meningkat, kemajuan teknologi, industri, dan transportasi menyebabkan luasan ketersediaan ruang terbuka hijau menjadi kurang diperhatikan oleh pemeritah sehingga pada tahun 2017 Pemerintah Kabupaten Pamekasan kesulitan memenuhi ruang terbuka hijau sebesar 30\%. Tujuan dari penelitian ini adalah mengidentifikasi ketersediaan lahan untuk penyediaan ruang terbuka hijau taman kota dan menentukan arahan pengembangan dan lokasi penambahan ruang terbuka hijautamankota. Metode analisa yang digunakan adalah deskriptif kuantitatif, dengan teknik analisis kebutuhan ruang terbuka hijau taman kota berdasarkan jumlah penduduk dan kesesuaian lahan. Berdasarkan hasil analisis penduduk Perkotaan Pamekasan tahun 2029 sebanyak 194.956 jiwa dengan kebutuhan lahan penyediaan ruang terbuka hijautaman kota seluas $58.486,8 \mathrm{~m}^{2}$ sedangkan eksisting luasan ruang terbuka hijautaman kota seluas $30.292,8 \mathrm{~m}^{2}$ maka dilakukan penambahan seluas $28.194 \mathrm{~m}^{2}$. Kesesuaian lahan rencana pola ruang untuk penyediaan taman kota sebesar $67 \%$ dengan luasan 2.867.032,5 $\mathrm{m}^{2}$ dan untuk penambahan lokasi taman kota disebar di $7 \mathrm{desa} /$ kelurahan di Perkotaan Pamekasan.
\end{abstract}

Kata Kunci : Arahan Pengembangan, Overlay Spasial, Ruang Terbuka Hijau Taman Kota 


\section{REFRENSI/DAFTAR PUSTAKA}

Basri, A. (2017). Pemerintah Sulit Penuhi RTH 30 Persen. JawaPos.com. https://radarmadura.jawapos.com/read/2017/11/28/30003/pemerintah-sulit-penuhi-rth-30persen, diakses pada 18 Oktober 2018.

Fachriani, N. (2017). Analisis Ketersediaan Ruang Terbuka Hijau dengan Menggunaka Aplikasi Sistem Informasi Geografis (SIG) di Kecamatan Pamerah Jakarta Barat. Skripsi. Fakultas Ilmu Tarbiyah dan Keguruan Universitas Islam Negeri Syarif Hidayatullah Jakarta.

Febrianti, N., Pasaribu, J. M., \& Sulma, S. (2015). Analisis ruang terbuka hijau DKI Jakarta menggunakan data spot 6. Prosiding Pertemuan Ilmiah Tahunan XX 2015, 3(4), 400-410.

Jihan, J. C. (2014). Pemanfaatan Global NAavigation Satellite System ( GNSS ) Untuk Pemetaan Penggunaan Lahan Di Kecamatan Sukolilo Surabaya Timur. 154-160.

Jihan, J. C. (2016). Pemetaan jaringan jalan terhadap aktivitas perdagangan dan jasa berbasis sig di kecamatan sukolilo surabaya timur. Waktu, 14. Retrieved from http://jurnal.unipasby.ac.id/index.php/waktu/article/download/137/49

Kementrian Pekerjaan Umum. (2008). Peraturan Menteri Pekerjaan Umum Nomor: 05/PRT/M/2008 Tentang Pedoman Penyedian dan Pemanfaatan Ruang Terbuka Hijau di Kawasan Perkotaan. Jakarta.

Pangesti, F. S. P., \& Dwirani, F. (2018). Analisis kesesuaian ruang terbuka hijau di kota Serang. Serambi Engineering, 3(5), 330-343.

Rahman, M. D., Awaluddin, M., \& Hani'ah. (2016). Analisis spasial ketersediaan ruang terbuka hijau terhadap jumlah penduduk di kota Solo. Jurnal Geodesi Undip, 5(3), 41-51. 